and at shallow depths where not emerged; that, therefore, the oceanic depression was then large and deep enough to hold the ocean. Further, this last fact indicates, if the mean level of the continents was coincident with the water's surface, that the oceanic depression had already a depth of 12,000 feet, or that of the present mean depth of the waters; and that the lowering, through later time, of the bed I 500 feet on an average (or 2000 feet according to other estimates) would give the continents their present mean height. And it is a fact of deep geogenic significance, that nearly 1000 feet of this mean height was received after the beginning of the Tertiary.

JAMES D. DANA.

\section{OPENING OF THE LIVERPOOL MARINE BIOLOGICAL STATION AT PORT ERIN.}

THE Liverpool Marine Biology Committee, which commenced the investigation of the fauna and flora of Liverpool Bay and the neighbouring seas seven years ago, and has kept up a smail biological station on Puffin Island, Anglesey, for the last five years, passed on Saturday (June 4) into a new phase of its existence, and, it may be hoped, a more extended sphere of labour, when His Excellency Spencer Walpole, Lieutenant-Governor of the Isle of Man, declared the new marine laboratory at Port Erin to be open for work. The Puffin Island establishment has been very useful to the Committee, and well worth the small annual expenditure required for its modest outfit. It has been used by a few students who wished to gain a general knowledge of the common marine animals and plants in a living state, and by a limited number of specialists who went there to make observations, or who had the material for their investigations collected there and sent to them. But the Committee has felt for the last year, at least, that a station which was more readily accessible from Liverpool, and with hotel or lodging accommodation obtainable on the spot, would enable their members to do more work, and be of more use both to students and to investigators. Also, it was evident that after five years' work on the shores of the small island the greater number of the plants and animals had been collected and examined, and that a change to a new locality with a rich fauna and a more extended line of coast would yield increased material for faunistic work. On looking round the Liverpool Marine Biology Committee's district, Port Erin, at the southern end of the Isle of Man, at once presented itself as the best available place.

From its position, and the shape of the land, Port Erin has within a distance of a couple of miles in three directions-to Fleshwick Bay, to the Calf, and to Port St. Mary - a long and varied coast-line, with a number of small bays, furnishing good collecting-ground and shallow-water dredging. Two of these bays, Port Erin and Port St. Mary, have harbours with sailing-boats, and face in nearly opposite directions, so that in most winds one or other is sheltered and has a quiet sea. The rich fauna around the Calf and off Spanish Head is within easy reach : at a distance of three to four miles from the laboratory are depths of 20 to 30 fathoms, and at fourteen miles 60 to 70 fathoms. Although it is a considerable distance from Liverpool, still it is reached by a regular service of swift steamers and convenient trains, so that there is no uncertainty or delay in the journey.

The plan of Port Erin shows the position and surroundings of the Biological Station. It is on the beach at one corner of the bay, near where the sand and rocks join, and at the foot of the cliff upon which the Bellevue Hotel stands. It is connected with the road by means of a winding gravel path and steps, and is about a third of a mile from the railway station. It is just at the bottom of the hotel grounds, and arrangements have been made with the proprietor by which those working at the Biological Station can live comfortably and economically at the hotel. The sea comes to within a few yards of the windows, and the bay immediately in front is sheltered pure sea-water with a varied bottom, suitable for small boat dredging and tow-netting; while the rocky coast, extending out towards Bradda Head, has many creeks and goud shore pools.

The station is a substantially built, three-roomed house, measuring a little over 30 feet by 20 feet, and standing on a solid stone and concrete platform, which raises it about Io feet above high tide. It has windows looking out in three directions, north, south, and west. The front door leads into a passage, from which open to right and left two small rooms, which can be used as the Director's room and the Secretary's office, and will also be available for the use of members of the Committee, or any special students who require a separate room for their work. Opposite the entrance is the door into the main laboratory, which measures about 22 feet by 20 feet, and has windows on beth sides. In front of the windows run strong fixed work-tables, which will accommodate five students with ease. At the ends of the room are fire-place, sink, tables, bookcase, and abundance

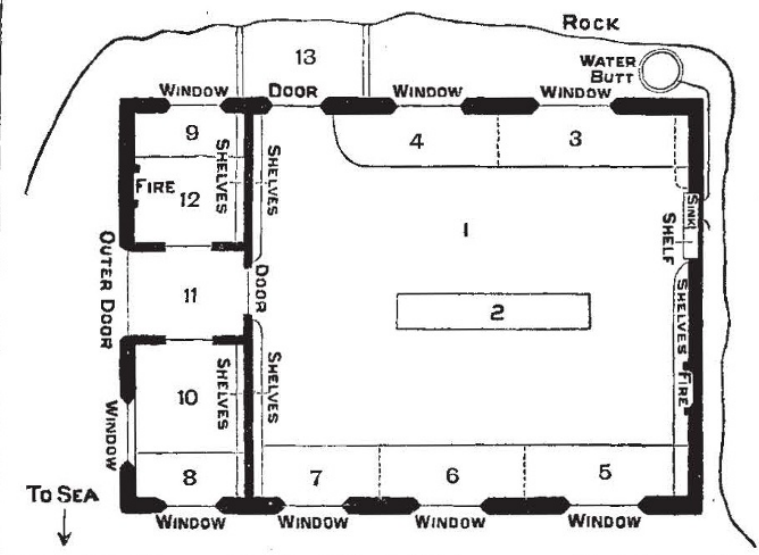

Plan of the Liverpool Marine Biological Laboratoly at Port Erin. I, Main laboratory $(22 \times 20)$. with work places for five students: 2 , strong table for aquaria ; 3 to 9 , tables; 10, small laboratory for Director or members of Committee ; Ir, passage '; I $_{2}$, small laboratory or Secretary's office; $\mathrm{r}_{3}$, small yard.

of shelving, while along the centre runs a strong table for small aquaria and vessels containing animals. A door in one corner opens into a useful small yard between the house and the cliff, in which the concrete fresh water cistern is placed, and where dredges and other implements can be stored.

The Liverpool Salvage Association had kindly promised to lend their useful steamer, the Hyana, to the Committee for four or five days at the time of opening; but as she was called off on duty at the last moment, they sent the steamer Mallard instead, on Friday afternoon, across to Port Erin, where she remained until Monday. Dredging trips in the neighbourhood took place on three of the days, and on Saturday evening tow-netting with submarine electric lights was carried on after dark in the bay.

At one o'clock on Saturday the Lieutenant-Gov'rnor, the Bishop, the Manx Attorney-General, and a number of members of the House of Keys, and others, arrived at Port Erin, where they were met by Prof. Herdman, Mr. I. C. Thompson, Mr. A. O. Walker, Mr. J. Vicars, Sir James Poole, and others of the L.M.B.C., along with some biologists from elsewhere, the Liverpool party numbering over thirty. The Governor was conveyed to the front of the Biological Station, where, after being presented by Prof. Herdman with the reports upon the

NO. I I 8 I, vOL. 46] 
fauna of Liverpool Bay published by the L.M.B.C., he declared the building open for work, and then the party entered and proceeded to examine the results of the forenoon's dredging, laid out in dishes and under microscopes. At two o'clock the Governor and the Bishop were entertained to luncheon at the Bellevue Hotel by the L.M.B.C., Prof. Herdman being in the chair, with the Governor on the right and the Bishop on the left. Mr. I. C. Thompson, Hon. Sec. L.M.B.C., occupied the other end of the table, and about seventy in all sat down to luncheon, including the President and Secretary and some other members of the Isle of Man Natural History Society. The Governor proposed the toast of "The Liverpool Marine Biology Committee," to which Prof. Herdman replied.

The whole of the following day was spent in dredging and tow-netting from the Mallard to the west and south of Port Erin at the following localities:-

(I) 3 miles west of Fleshwick: 20 fathoms, 6 hauls of dredge: good varied ground, old shells, \&c.

(2) I4 miles west of Dalby: 60 fathoms, 2 hauls; sticky clay mud, with few animals.

(3) 8 miles west of Fleshwick: 33 fathoms, 3 hauls.

(4) 6 miles west of Port Erin: 24 fathoms, 2 hauls.

(5) I mile west of Calf : 20 fathoms, 2 hauls.

(6) Off Kitterland, Calf Sound: I7 fathoms, I haul.

At each of these localities, besides the ordinary large dredge, tow-nets were used, and also Mr. Walker's small dredge with a canvas bag for bringing up samples of the bottom to be washed for small Crustacea, \&c.

On the following day (June 6), on the way back to Liverpool, dredging from the Mallard was conducted at the following places:-

(1) 20 miles south-east from Port St. Mary : 26 fathoms.

(2) 25 miles south-east from Port St. Mary : 23 fathoms.

Both of these localities were good productive ground, and large hauls were obtained.

(3) 20 miles north-west from the Bar: I 8 fathoms.

(4) 15 miles north-west from the Bar: 16 fathoms.

On all these occasions, besides the surface tow-nets, a bottom tow-net was attached a little way in front of the dredge, and appeared to work well; its contents were usually a good deal different from those of the surface nets.

Amongst the forms dredged in these two days were :Clathria seriata, Spongelia fragilis, Sarcodictyon catenata, Palmipes memoranaceus, Stichaster roseus, Porania pulvillus, Antedon rosaceus, Adamsia pailliata, Crania anomala, Pansora incquivalvis, Cynthia echinata, and the rare little Ascidian Forbesella tessellata, and a large number of other species, representing most of the invertebrate groups, which have not yet been sorted out and identified. A list of the species previously found in the neighbourhood of Port Erin will be found in "Fauna of Liverpool Bay," vol. i. pp. 318-4I.

The Liverpool Marine Biology Committee's Station at Port Erin is now open, and is provided with a few microscopes, microtome, ordinary reagents, dishes, \&c. Any biolingists wishing to go there for collecting or other work are requested to apply for particulars to Prof. Herdman, or to Mr. I. C. Thompson, 4 Lord Street, Liverpool.

\section{THE ANNUAL VISITATION OF THE} GREENWICH OBSERVATORY.

THE report of the Astronomer-Royal to the Board of Visitors this year commences with a reference to the loss sustained by the Observatory by the death of Sir G. B. Airy, who for sixty years was closely connected with the working of this institution.

As regards the buildings, that of the south wing of the proposed Physical Observatory has been authorized by No. I I 8 I, VOL. 46$]$ the Admiralty, considerably more space being required for the storing of chronometers and deck watches. The buildings of the three other wings and the two upper stories of the central tower have, for the present, been laid aside, sufficient provision not being made for them in the present financial year. The new 36 -foot dome, which is being provided for the efficient working of the 28 -inch refractor, is still in course of erection, while the pair of semi-domes for the Transit Pavilion in the Front Court has been found to be quite satisfactory. The electric light installation, which has in a former report been suggested by the Astronomer-Royal for the photographic equatorial and for other instruments, has been sanctioned by the Admiralty, and will, during the course of the present year, be provided. The advantages of such a means of lighting will at once make themselves apparent, for by the old method the storage cells had to be charged from primary batteries.

The Observatory, by the will of the late Sir George Airy, has had several valuable works bequeathed to it. Mr. Wilfred Airy has as yet transferred 94 volumes and I34 unbound tracts, which will form a valuable addition to the library, together with the manuscript containing the calculations of Sir George Airy's numerical lunar theory. His bust, by Foley, has also been received and is now placed in the Octagon Room.

With regard to the work done with the transit-circle, the number of observations was not so great as in former years, as the object-glass was removed for repolishing on August 10 to October 5. The definition and colourcorrection of this glass has been greatly improved by $\mathrm{Mr}$. Simms. New steel screws to the R.A. and Z.D. micrometers were added at the same time, and the wire system also received a slight modification. The wires are ten in number, distant from each other by exact multiples of a screw-revolution, and so arranged that the mean of the ten nearly coincides with one of them. A little computation is thus saved in taking the mean of a transit, and the only thing lost is symmetry in the arrangement.

During the rest of the year the sun, moon, and planets have been regularly observed on the meridian as before :-

Transits, the separate limbs being counted as

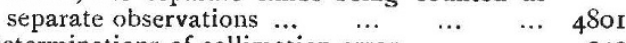

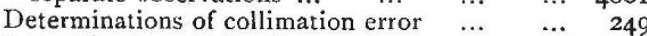

Determinations of level error $\quad \ldots \quad \ldots \quad \ldots \quad \ldots \quad 335$

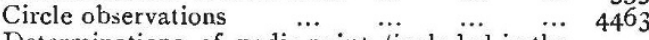

Determinations of nadir point (included in the number of circle observations)

Reflexion observations of stars (similarly included) ...

The annual catalogue of stars observed in I89I contains 18 I 3 stars.

The results from the observations for the determination of variation of personal equation with stellar magnitude, indicated that there was a general tendency with all the observers to observe stars later when the light was diminished by placing a gauze screen before the objectglass; but it was stated that "it is not clear that we are here measuring a real change of personal equation in observations of fainter stars, as the introduction of the screen modifies the image of the star, and this modification of the image may give rise to a change of personal equation unconnected with the diminution of brightness."

It is noted that as the external thermometer rises there is a nearly uniform decrease of the readings of the internal thermometers over that of the standard exterior thermometer, the excess vanishing at something over $70^{\circ}$. This is accounted for by the variation of the temperature of the walis of the room, the permanent temperature of which is always slowly changing. 